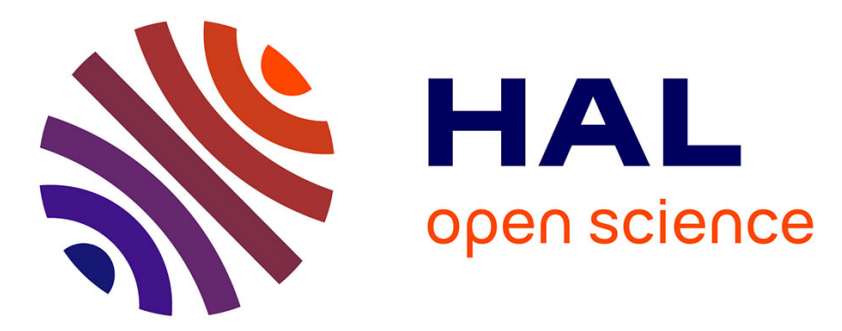

\title{
BMPs and BMPRs in chicken ovary and effects of BMP-4 and -7 on granulosa cell proliferation and progesterone production in vitro
}

O.M. Onagbesan, V. Bruggeman, P. van As, Kokou Tona, John Williams, Eddy Decuypere

\section{To cite this version:}

O.M. Onagbesan, V. Bruggeman, P. van As, Kokou Tona, John Williams, et al.. BMPs and BMPRs in chicken ovary and effects of BMP-4 and -7 on granulosa cell proliferation and progesterone production in vitro. AJP - Endocrinology and Metabolism, 2003, 285 (5), pp.E973-E983. hal-02680999

\section{HAL Id: hal-02680999 \\ https: / hal.inrae.fr/hal-02680999}

Submitted on 31 May 2020

HAL is a multi-disciplinary open access archive for the deposit and dissemination of scientific research documents, whether they are published or not. The documents may come from teaching and research institutions in France or abroad, or from public or private research centers.
L'archive ouverte pluridisciplinaire HAL, est destinée au dépôt et à la diffusion de documents scientifiques de niveau recherche, publiés ou non, émanant des établissements d'enseignement et de recherche français ou étrangers, des laboratoires publics ou privés. 


\section{O. M. Onagbesan, V. Bruggeman, P. Van As, K. Tona, J. Williams and E. Decuypere}

Am J Physiol Endocrinol Metab 285:973-983, 2003. First published Jul 29, 2003;

doi:10.1152/ajpendo.00104.2003

You might find this additional information useful...

This article cites 39 articles, 29 of which you can access free at:

http://ajpendo.physiology.org/cgi/content/full/285/5/E973\#BIBL

This article has been cited by 1 other HighWire hosted article:

Expression and biological effects of bone morphogenetic protein-15 in the hen ovary

S Elis, J Dupont, I Couty, L Persani, M Govoroun, E Blesbois, F Batellier and P Monget

J. Endocrinol., September 1, 2007; 194 (3): 485-497.

[Abstract] [Full Text] [PDF]

Updated information and services including high-resolution figures, can be found at:

http://ajpendo.physiology.org/cgi/content/full/285/5/E973

Additional material and information about AJP - Endocrinology and Metabolism can be found at: http://www.the-aps.org/publications/ajpendo

This information is current as of September 3, 2010 . 


\title{
BMPs and BMPRs in chicken ovary and effects of BMP-4 and -7 on granulosa cell proliferation and progesterone production in vitro
}

\author{
O. M. Onagbesan, ${ }^{1}$ V. Bruggeman, ${ }^{1}$ P. Van As, ${ }^{1}$ K. Tona, ${ }^{1}$ J. Williams, ${ }^{2}$ and E. Decuypere ${ }^{1}$ \\ ${ }^{1}$ Laboratory for Physiology and Immunology of Domestic Animals, Catholic University \\ of Leuven, B-3001 Heverlee, Belgium; and ${ }^{2}$ Station de Recherches Avicoles, \\ Institut National de la Recherche Agronomique, 37380 Nouzilly, France
}

Submitted 12 March 2003; accepted in final form 22 July 2003

\begin{abstract}
Onagbesan O. M., V. Bruggeman, P. Van As, K. Tona, J. Williams, and E. Decuypere. BMPs and BMPRs in chicken ovary and effects of BMP-4 and -7 on granulosa cell proliferation and progesterone production in vitro. $A m \mathrm{~J}$ Physiol Endocrinol Metab 285: E973-E983, 2003. First published July 29, 2003; 10.1152/ajpendo.00104.2003.-Bone morphogenetic proteins (BMPs) and their receptors (BMPRs) are now known to have important roles in mammalian ovarian folliculogenesis. This study determined the expression of the mRNA encoding for BMPs and their receptors in the chicken ovary and explored possible roles for them. The expression of the mRNA for BMP-2, -4, -6, -7, and BMPR-IA, -IB, and -II was determined and quantified by a semiquantitative RT-PCR. The mRNAs for all the BMPs and receptors determined were present in both the granulosa $(\mathrm{G})$ and theca (T) cells of the F1, F2, and F3 follicles. All BMP mRNAs increased in $\mathrm{G}$ cells with follicular development, whereas only BMP-7 mRNA had this trend in the T cells. BMP-2, -4 , and -6 mRNAs in T were similar between follicles. BMPR-IA mRNA was similar in F2G and F3G but lower in F1G. BMPR-IB mRNA was similar in G of all follicles, and BMPR-II mRNA increased with development. In the $\mathrm{T}$, each receptor subtype showed equal distribution between follicles. mRNA levels for BMPR-IB and -II were higher in $G$ than in $T$, suggesting that the $\mathrm{G}$ is a major target for BMPs. BMP-4 and -7 stimulated basal, IGF-I-, and gonadotropin-stimulated progesterone production by cultured G cells, with differential responses between cells from the F1 and F3/4. This suggests involvement in follicular differentiation. BMP-4 and -7 reversed the inhibitory effects of transforming growth factor (TGF)- $\alpha$ on basal and gonadotropin-stimulated $\mathrm{G}$ cell progesterone production, with greater effect in the F1 than in the F3/4. This effect suggests an important role for BMPs interacting with TGF- $\alpha$ in modulating the effects of gonadotropins and IGF-I on follicular differentiation. Finally, BMP-7 stimulated $\mathrm{G}$ cell proliferation, but BMP-4 inhibited TGF- $\alpha$ + IGF-Iand/or FSH-stimulated G cell proliferation, suggesting a role in the control of follicular growth during development. These effects of BMP-4 and -7 on the G cell function showed relationships with the expression levels of the BMPs and the BMPR-II.
\end{abstract}

chicken; bone morphogenetic proteins; bone morphogenetic protein receptors; theca; steroidogenesis

THE BONE MORPHOGENETIC PROTEINS (BMP) are a group of growth and differentiating factors belonging to the

Address for reprint requests and other correspondence: O. M. Onagbesan, Laboratory for Physiology and Immunology of Domestic Animals, Catholic Univ. of Leuven, Karsteelpark, Arenberg 30, B-3001 Heverlee, Belgium (E-mail: Okanlawon.Onagbesan@agr.kuleuven.ac.be). transforming growth factor- $\beta$ superfamily. By molecular cloning, at least 15 members of the group have been identified and are called BMP-2 through BMP-15. The BMPs signal via complexes of serine/threonine kinase types I and II receptors that have been designated BMPR-IA, BMPR-IB, and BMPR-II. In vertebrates, the BMPs have been implicated in several functions during both embryonic and postembryonic life. These functions include formation of bones, cartilage (25), neurons (1), teeth (7), eyes, kidney (8), and feathers (2). They are also involved in the delivery of positional information, including organogenesis, tissue patterning, and remodeling (14,32). However, a virtually unexplored role in the reproductive tissues is emerging. Recently, it was shown that the BMPs and their receptors are involved in the autocrine/paracrine regulation of ovarian folliculogenesis in some mammals. BMP-2, -4, -6, -7, and -15 , and their receptors have been specifically implicated in rat, sheep, and cattle ovarian function. In rat, the mRNA encoding BMP-4 and -7 are expressed in the theca, whereas those encoding the BMP-6 and BMP-15 are confined to the oocytes of the follicles. All BMPRs are expressed in the granulosa, theca, and oocyte $(4,11,28)$. In this species, BMP-4, - 7 , and -15 regulate granulosa cell steroidogenesis, whereas BMP-6 and -15 induce cell proliferation $(10,21,22,28)$. In sheep, a crucial role for the BMPs in the regulation of ovarian folliculogenesis has been established since the discovery that the presence of heterozygous mutation in the BMP-15 gene results in improved prolificacy in Inverdale, known as FecX, ewes (5). On the other hand, carrying Q249R mutations in the BMPR-IB also confers improved prolificacy on Booroola, or FecB, ewes $(15,31)$. Except for BMP-15, there is a dearth of information on the types of BMPs that are expressed in the sheep ovary and their functional significance. Souza et al. (30) reported the localization of BMPR-IA, -IB, and -II in the granulosa $(\mathrm{G})$ and to a lesser extent in the theca $(\mathrm{T})$ of the sheep ovary. These authors and Wilson et al. (37) have demonstrated that BMP-2 and -4 regulated G cell steroidogenesis in sheep.

The costs of publication of this article were defrayed in part by the payment of page charges. The article must therefore be hereby marked "advertisement" in accordance with 18 U.S.C. Section 1734 solely to indicate this fact. 
In the avian species, the gene expression or a role for the BMPs in the ovary is still unexplored. Previous studies have shown that other growth factors, such as IGF-I, EGF, TGF- $\alpha$, TNF- $\alpha$, and FGF, are expressed in the chicken ovary and perform important roles alone or in their interaction with $\mathrm{LH}, \mathrm{FSH}$, or GH in the regulation of follicle growth and differentiation (17-19, 24, 39 ). The aim of the current study was to determine the expression of mRNA encoding BMP-2, $-4,-6$, and -7 and of their receptors BMPR-IA, -IB, and -II in the chicken ovary. Having found the transcripts of the BMPs and BMPRs, we further determined the effects of two of the highly expressed BMPs, BMP-4 and -7, on G cell progesterone production and proliferation in culture. The effects of their interaction with $\mathrm{LH}, \mathrm{FSH}$, and other growth factors (IGF-I, IGF-II, and TGF- $\alpha$ ) on these functions were also determined.

\section{MATERIALS AND METHODS}

\section{Gene Expression of BMPs and BMPRs}

Animals and tissue collection for gene expression. Laying "Label" broiler breeder hens (Hubbard Europe, Quintin, France) of 35-40 wk of age were kept in cages under a 16:8-h light-dark photoperiod. Chickens were allowed food and water ad libitum, and laying was monitored daily. Hens were killed by cervical dislocation $4-8 \mathrm{~h}$ before the next oviposition. The largest (F1), second largest (F2), and third largest (F3) follicles were excised from the ovary into warmed $\left(37^{\circ} \mathrm{C}\right)$ phenol-free Hanks' balanced salt solution (pfHBSS; SigmaAldrich, Bornem, Belgium). The G cell layer of the follicles was dissected out, as previously described (6). Tissues were immediately snap-frozen in liquid nitrogen and stored at $-80^{\circ} \mathrm{C}$ until used for total RNA isolation.

RNA isolation. Total RNA was extracted from chicken G and $\mathrm{T}$ tissues using the TRIzol reagent (Invitrogen, Merelbeke, Belgium). The RNA concentration was estimated by reading the absorbance at $260 \mathrm{~nm}$ and was checked for purity at $280 \mathrm{~nm}$ in a spectrophotometer (GeneQuant, Pharmacia Biotech, Cambridge, UK). The samples were stored at $-80^{\circ} \mathrm{C}$.

Primer sets. The primer sets used for this study were designed with a computer program (DNAman for Windows, Lynnon Biosoft). Primers were selected from published chicken and quail sequences. The upstream and downstream primer sets, their sources, and the predicted product sizes are as shown in Table 1.

Protocol. The expression of the mRNA for each BMP and BMPR was first determined in the $\mathrm{G}$ and $\mathrm{T}$ of the different follicle sizes (F1G, F2G, F3G, F1T, F2T, and F3T). Then, with the housekeeping gene GAPDH as control to demonstrate equal loading of the lanes, mRNA level in the tissues of the different follicle sizes was determined.

Reverse transcription. Complementary DNA was synthesized by the extension of respective antisense primers. Nineteen microliters of RT master mix for each sample $(1 \mu \mathrm{g}$ of total RNA) were prepared by using single-strength firststrand buffer (Invitrogen), 5 U of RNasin (Promega, Leiden, The Netherlands), $10 \mathrm{U}$ of Moloney murine leukemia virus RT (Invitrogen), 0.5 mM PCR nucleotide mix (Promega), 5 $\mathrm{mM}$ DTT (Invitrogen), and $1 \mu \mathrm{M}$ of antisense primer, separately. The RT reaction was carried out in a DNA thermal cycler (MJ-PTC-200, Biozym, Landgraaf, The Netherlands) at $37^{\circ} \mathrm{C}$ for $45 \mathrm{~min}$ followed by $5 \mathrm{~min}$ at $95^{\circ} \mathrm{C}$. The samples were then placed on ice immediately and later were used further for amplification.

PCR amplification and quantification of mRNA. PCR was performed for each BMP and BMPR by adding the following components to the reaction mixture: 10× REDTaq DNA polymerase buffer (Sigma, St. Louis, MO), $0.25 \mathrm{mM}$ PCR nucleotide mix (Promega), 0.5 $\mu \mathrm{M}$ of each primer, and 7.5 $\mathrm{U}$ of REDTaq DNA polymerase (Sigma) in a total volume of 40 $\mu \mathrm{l}$. The PCR reaction for BMPR-IA was performed as follows: $95^{\circ} \mathrm{C}$ for $3 \mathrm{~min} ; 30$ cycles at $94^{\circ} \mathrm{C}$ for $45 \mathrm{~s}, 52.5^{\circ} \mathrm{C}$ for $45 \mathrm{~s}$, and $72^{\circ} \mathrm{C}$ for $20 \mathrm{~s}$; and a final extension for $5 \mathrm{~min}$ at $72^{\circ} \mathrm{C}$. The PCR reaction for BMP-2, -4, -6, and -7 was performed as follows: $95^{\circ} \mathrm{C}$ for $3 \mathrm{~min} ; 30$ cycles at $94^{\circ} \mathrm{C}$ for $45 \mathrm{~s}$, at $54^{\circ} \mathrm{C}$ for $45 \mathrm{~s}$, and at $72^{\circ} \mathrm{C}$ for $25 \mathrm{~s}$; and a final extension for 5 min at $72^{\circ} \mathrm{C}$. The PCR reaction program for BMPR-IB and BMPR-II was at $95^{\circ} \mathrm{C}$ for $3 \mathrm{~min} ; 30$ cycles at $94^{\circ} \mathrm{C}$ for $45 \mathrm{~s}$, at $54.5^{\circ} \mathrm{C}$ for $45 \mathrm{~s}$, and at $72^{\circ} \mathrm{C}$ for $25 \mathrm{~s}$; and a final extension for $5 \mathrm{~min}$ at $72^{\circ} \mathrm{C}$. Fifteen microliters of PCR products were electrophoresed on a $2 \%(\mathrm{wt} / \mathrm{vol})$ agarose gel (Invitrogen) containing $1 \%$ ethidium bromide. A 100-bp DNA ladder (Eurogentec, Herstal, Belgium) was used as molecular weight standard. Negative control RT-PCR with diethyl pyrocarbonate-treated water was included in all experiments.

After electrophoresis, the gel was scanned, and the intensities of the different bands were measured with a densitometer (Image Master VDS, Pharmacia Biotech, Uppsala, Sweden) as previously described $(26,33)$. Data were normalized to GAPDH mRNA abundance and expressed as a percentage.

\section{Effects of BMP-4 and -7 on Cultured G Cells}

Chicken $G$ cell preparation and culture. Laying Label broiler breeder hens of 35-40 wk of age were kept in cages under a 16:8-h light-dark photoperiod. Chickens were allowed food and water ad libitum, and laying was monitored daily. Hens were killed by cervical dislocation $4-8 \mathrm{~h}$ before the next oviposition. The F1, F3, and F4 follicles were excised from the ovary into warmed $\left(37^{\circ} \mathrm{C}\right)$ pfHBSS (Sigma-Aldrich). The G cell layer of the follicles was dissected out, as previously described (6), and dispersed in $\mathrm{Ca}^{2+} / \mathrm{Mg}^{2+}$-free Hanks'

Table 1 Primer pairs

\begin{tabular}{|c|c|c|c|c|c|c|}
\hline & Species & EMBL Ac. No. & Position & Length & Sense Primer & Antisense Primer \\
\hline BMP-2 & Chicken & X75914 & $339-662$ & $324 \mathrm{bp}$ & 5' GGTGCACGAAGCCTTTGAGA 3' & $5^{\prime}$ AACAACGGCCTGAGCTGAGA 3' \\
\hline BMP-4 & Chicken & X75915 & $87-445$ & $359 \mathrm{bp}$ & 5' GACCGGCAGGAAGAAAGTCG 3' & 5' GCACGCTGCTGAGGTTGAAG 3' \\
\hline BMP-6 & Chicken & BM440114 & $57-424$ & $368 \mathrm{bp}$ & 5' CACGCCATCGTCCAAACTCT 3' & 5' CTGCAGCATAGGGTCGCATT 3' \\
\hline BMP-7 & Chicken & AF223970 & $86-327$ & $242 \mathrm{bp}$ & $5^{\prime}$ CCGACTTCACGCTGGACAAC $3^{\prime}$ & $5^{\prime}$ GTAGGAGAAGCCCTCGCCCT $3^{\prime}$ \\
\hline BMPR-1A & Quail & AF189777 & $805-1031$ & $227 \mathrm{bp}$ & 5' GAAGCCAGTTGGTTCCGAGA 3' & 5' CACAGACCACATGCAGCAGA $3^{\prime}$ \\
\hline BMPR-1B & Quail & AF189778 & $643-853$ & $211 \mathrm{bp}$ & $5^{\prime}$ GACATCCCTCCAAACACCCG 3' & $5^{\prime}$ GGTCACTGGGCACAAGGTCA 3' \\
\hline BMPR-2 & Chicken & L77660 & $100-378$ & $279 \mathrm{bp}$ & $5^{\prime}$ GGAATCAGCGAGAGCCGAAT $3^{\prime}$ & 5' TGGGTCAGGAGGTGGGAAGT $3^{\prime}$ \\
\hline
\end{tabular}

Ac. No., accession no.; BMP, bone morphogenetic protein; BMPR, BMP receptor. 
solution (Sigma) containing $0.1 \mathrm{mg} / \mathrm{ml}$ collagenase (Sigma), as described previously (23). Cells from follicles of the F1 or F3 and F4 positions were pooled from 5-6 hens, and the cell density was determined by measuring the DNA in aliqouts using the method of Labarca and Paigen (9), in which $1 \mu \mathrm{g}$ $\mathrm{DNA}=10^{5}$ cells. Cell viability was assessed by the Trypan blue method and was usually $>90 \%$. Cells were resuspended in Medium 199 (M199; Sigma-Aldrich) supplemented with 2 mmol glutamine/l, $40 \mathrm{mmol}$ sodium bicarbonate/l, 1\% (vol/ vol) PSA (antibiotic-antimycotic solution; Sigma), and 1\% BSA (Sigma). During preliminary studies, experiments were conducted to test the response of freshly isolated cells under short-term 3 -h incubation. Cells $\left(1 \times 10^{5}\right)$ were incubated in $0.5 \mathrm{ml}$ of medium at $39^{\circ} \mathrm{C}$ in the presence of different concentrations of ovine LH, ovine FSH (from Dr. Parlow, National Institute of Diabetes and Digestive and Kidney Diseases, Bethesda, MD), recombinant chicken IGF-I (Immunological and Biochemical Testsystems, Reutlingen, Germany), human recombinant BMP-4 and BMP-7 supplied with carrier proteins (R\&D Systems Europe, Abingdon, UK), and human recombinant TGF- $\alpha$ (Sigma-Aldrich). Because there was no effect of the BMPs and IGF-I on progesterone production, whereas LH and FSH dose dependently increased progesterone production under the short-term incubation conditions, a cell culture method was adopted. For cultures, cells were resuspended in M199 (Sigma-Aldrich) supplemented with 2 mmol glutamine/l, $40 \mathrm{mmol}$ sodium bicarbonate/l, $1 \%$ (vol/ vol) PSA (antibiotic-antimycotic solution; Sigma), and 5\% FBS (Invitrogen) and plated at $1.0 \times 10^{5}$ viable cells per well (equivalent to $1 \mu \mathrm{g}$ of DNA/well) in 24-well plastic plates (Iwaki). Cells were cultured for $24 \mathrm{~h}$ in a humidified atmosphere of $5 \% \mathrm{CO}_{2}$ in air at $37^{\circ} \mathrm{C}$ to establish cultures and to facilitate firm cell attachments, especially for the F1 cells. After this initial period of culture, the medium was discarded, and monolayer cells were washed with pfHBSS. Some plates were withdrawn to evaluate the number of cells attached to plates at the beginning of the final culture phase for testing hormone effects. (The DNA content of wells was between 0.7 and $0.82 \mu \mathrm{g} /$ well for the F1 and F3/4 cultures). This was followed by a further $48 \mathrm{~h}$ of culture in serum-free M199 supplemented with $2 \mathrm{mmol}$ glutamine/l, $40 \mathrm{mmol}$ sodium bicarbonate/l, $1 \%$ PSA, $6.25 \mu \mathrm{g} / \mathrm{ml}$ transferrin, $5 \mathrm{ng} / \mathrm{ml}$ selenium, and $0.1 \%$ (wt/vol) BSA (Sigma). All additions of test hormones were made in the second period of culture for $48 \mathrm{~h}$.

Effect of BMPs on progesterone production by $G$ cells. G cells from F1 (F1G) and F3/4G follicles were cultured for $48 \mathrm{~h}$ in the presence of increasing concentrations $(0-500 \mathrm{ng} / \mathrm{ml})$ of recombinant human $\mathrm{BMP}-4$ or -7 , initially to determine the dose effect of the BMPs. Because the effect of the BMPs was maximal at $50 \mathrm{ng} / \mathrm{ml}$ (see Fig. 5), subsequent tests were conducted to test the minimum $(1 \mathrm{ng} / \mathrm{ml})$ and a submaximal $(5 \mathrm{ng} / \mathrm{ml})$ effective dose. Cells were cultured in the presence of these doses of BMP with or without a submaximal concentration of recombinant chicken IGF-I ( $5 \mathrm{ng} / \mathrm{ml}$ ), recombinant human TGF- $\alpha(0.05 \mathrm{ng} / \mathrm{ml})$, or ovine LH or FSH $(5 \mathrm{ng} / \mathrm{ml})$. Various combinations of these hormones with the BMPs were also tested. The total incubation volume in all experiments was always $500 \mu \mathrm{l} /$ well. At the end of the incubation period, medium was collected and stored at $-20^{\circ} \mathrm{C}$ until assayed by radioimmunoassay for progesterone content.

At the end of all experiments, the final DNA content of the culture wells was determined and used to correct the progesterone production data, because the values of progesterone production will depend on the number of cells in the wells.

Progesterone assay. Progesterone concentration in the culture medium was determined by radioimmunoassay without extraction. Assay was conducted with a commercial kit (ICN Biomedicals, Costa Mesa, CA). The cross-reactivities of the antiserum in the kit with other ligands are $5.46 \%$ for 20 $\alpha$-dihydroprogesterone, $3.8 \%$ for desoxycorticosterone, and $<1 \%$ for other steroids. The sensitivity of the assay was 0.05 $\mathrm{ng} / \mathrm{ml}$. The intra-assay and interassay coefficients of variation were 5.20 and $8.44 \%$, respectively.

DNA assay. Cultures for DNA determination were washed in pfHBSS. The cells were disaggregated with $200 \mu \mathrm{l}$ of trypsin-EDTA (Roche) in TNE buffer (10 mmol Tris/l, $1 \mathrm{mmol}$ EDTA/l, and $2 \mathrm{M} \mathrm{NaCl}, \mathrm{pH}$ 7.0) followed by sonication. The DNA in aliquots of the lysate was determined by the method of Labarca and Paigen (9) by use of calf thymus DNA (Sigma) as standard and H-33258 (bisbenzimide; Sigma) as fluorogen. The DNA was quantified on a TKO 100 minifluorometer (Hoeffer Scientific Instruments, San Francisco, CA). The sensitivity of the assay was $0.25 \mathrm{ng} / \mathrm{ml}$, and the standard curve ranged between 0.0 and $10 \mu \mathrm{g} / \mathrm{ml}$.

\section{Statistical Analysis}

Data for mRNA expression represent means \pm SE of experiments repeated four times, each using pools of total RNA from the F1, F2, and F3 follicles of two hens.

Data presented for progesterone and DNA assays are means $\pm \mathrm{SE}$ of four experiments, each with four replicate culture wells. Data were analyzed by analysis of variance (ANOVA). Statistical differences were assessed by Duncan's multiple range test (General Linear Models procedure 1985; SAS Institute, Cary, NC). $P$ values of $<0.05$ were considered statistically significant.

\section{RESULTS}

\section{Presence of mRNA Encoding BMPs and BMPRs}

Figure 1, $A$ and $B$, shows the transcripts of BMP-2, $-4,-6$, and -7 and BMPR-IA, -IB, and -II in the G and T tissues of the chicken follicle. The mRNA for all BMPs and BMPRs was detected in the G and T of the F1, F2,

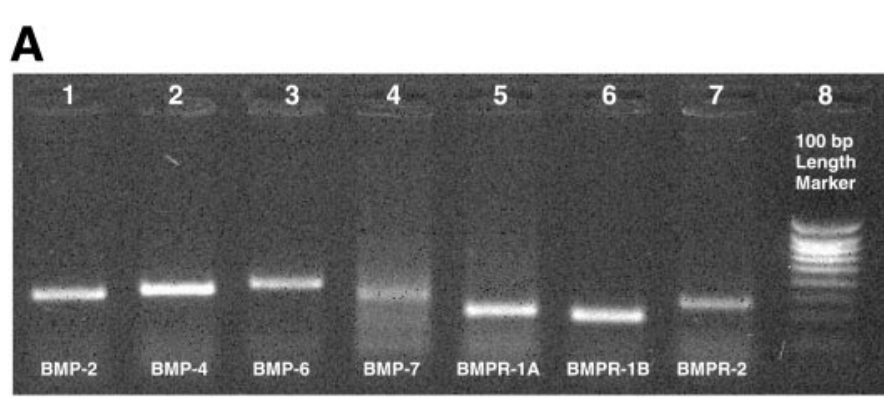

B

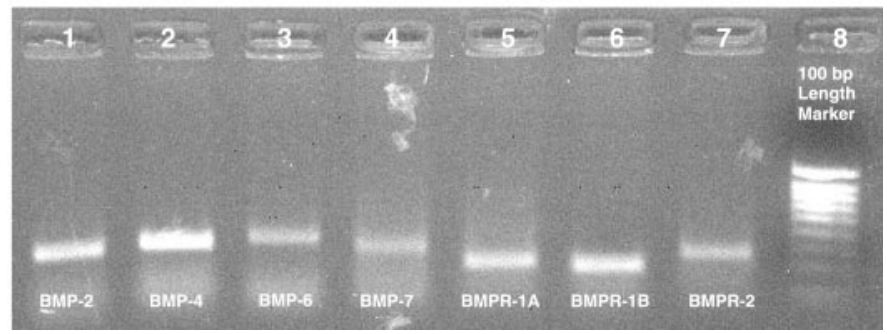

Fig. 1. Expression of the mRNAs encoding for bone morphogenetic proteins (BMP)-2, -4, -6, and -7 and their receptors (BMPR)-IA, -IB, and $-\mathrm{II}$ in the granulosa $(A)$ and theca $(B)$ of the chicken ovary determined by RT-PCR. 
and F3 follicles. Gel electrophoretic analysis showed that the transcripts were of the exact molecular size predicted. The products were confirmed further by restriction site digestion and sequencing.

\section{BMP mRNA Levels in $G$ and $T$ Cells}

The comparative levels of the mRNA in the G and T of all follicles were determined by reference to GAPDH levels. Figure 2 shows a typical assay for comparing the level of BMP-7 or BMPR-IA with GAPDH levels in the $\mathrm{G}$ or $\mathrm{T}$ of F1, F2, and F3 follicles.

The comparative levels of BMP-2, $-4,-6$, and -7 in the $\mathrm{G}$ or $\mathrm{T}$ of F1, F2, and F3 are shown in Fig. 3. BMP-2, -4, -6 , and -7 mRNAs were significantly higher in F1G and F2G than in the F3G, but there was no difference in the levels between the F1G and F2G.

In the $\mathrm{T}$ cells, there were no significant differences in the expression of BMP-2 or BMP-4 in the F1, F2, or F3. However, the level of BMP-7 was higher in the F1 and F2 than in the F3. The expression levels in the F1 and F2 were similar. BMP-6 mRNA was higher in the F2 than in the F3, with the level in the F1 between levels in F2 and F3.

Between tissues, BMP-2 was not significantly different in all follicles between the G and the T. BMP-4 in the F3 was similar between the $\mathrm{G}$ and $\mathrm{T}$ tissues but was higher in the G cells of the F1 and F2. BMP-6 was

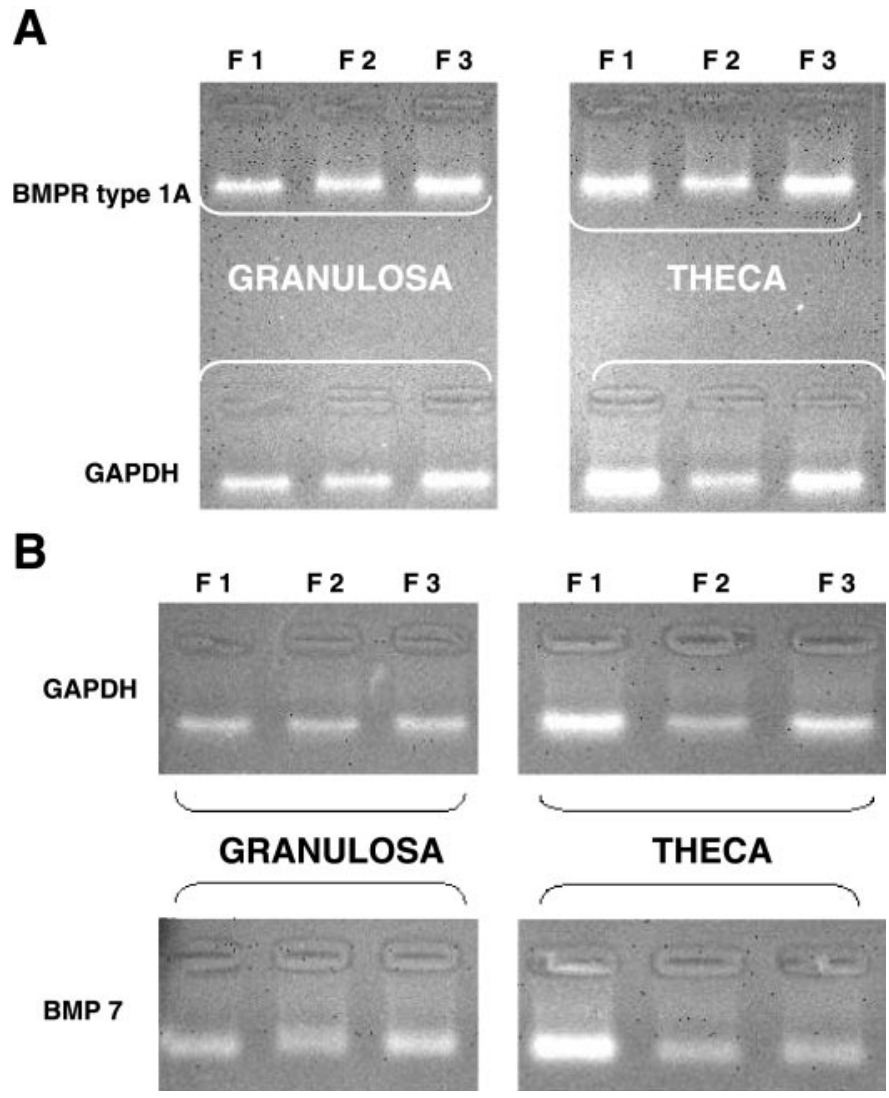

Fig. 2. Representative semiquantitative RT-PCR of mRNAs of the BMPs and BMPRs in granulosa and theca cells of the chicken ovary. Photos shows transcripts from BMPR-IA $(A)$ and BMP-7 $(B)$ compared with the expression of GAPDH.
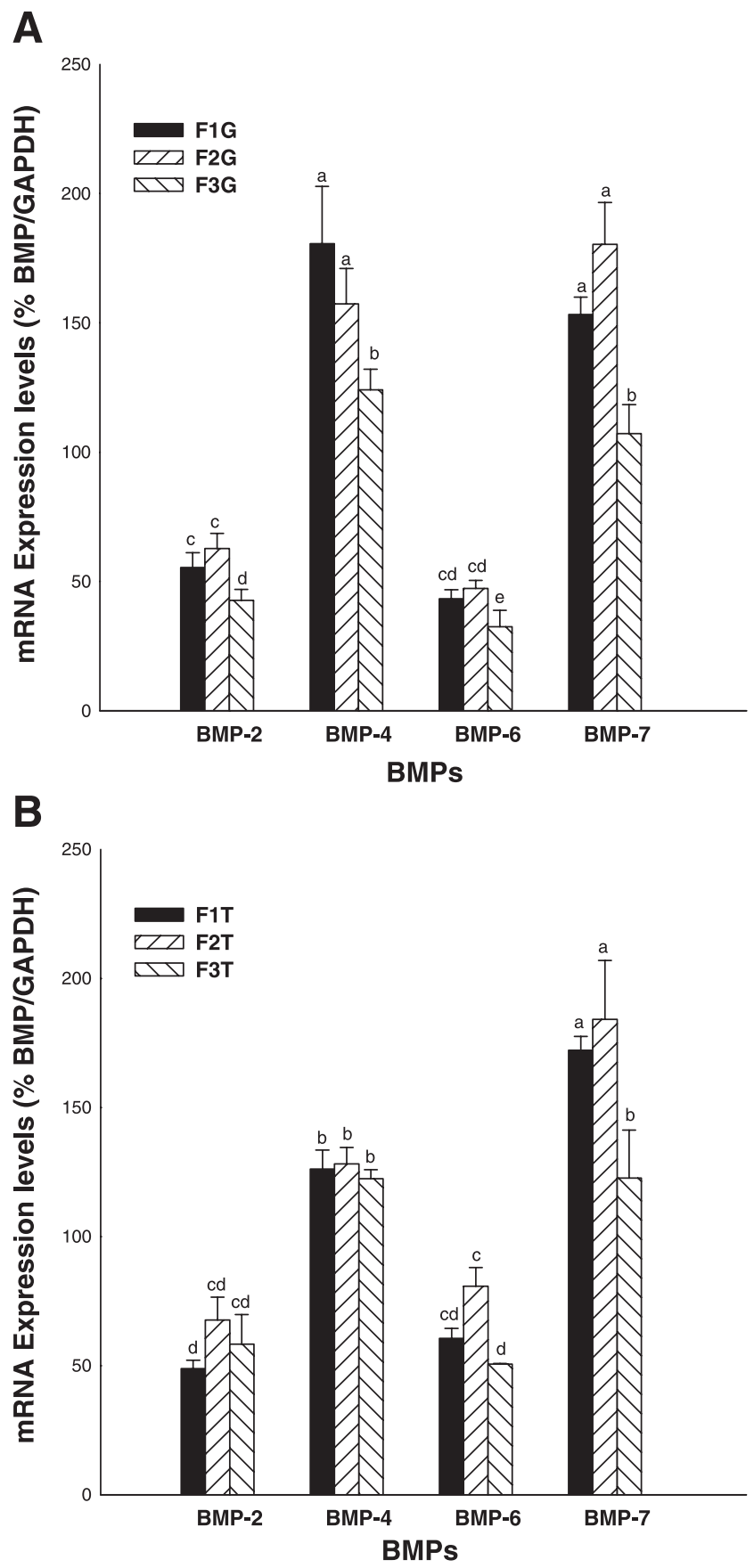

Fig. 3. Levels of expression of mRNA for BMP-2, $-4,-6$, and -7 in the granulosa $(A)$ and theca $(B)$ cells of the F1, F2, and F3 follicles of the chicken ovary $(n=4)$. Superscripts abcde represent statistical comparison between levels of BMPs. Bars with different letters are significantly different $(P<0.05)$.

significantly higher in the $\mathrm{T}$ of follicles compared with the levels in the G cells. BMP-7 showed similar levels of transcripts in the $\mathrm{T}$ and $\mathrm{G}$ of all follicles.

\section{BMPR mRNA Levels in G and T Cells}

The comparative transcript levels of BMPR-IA, -IB, and $-\mathrm{II}$ in the $\mathrm{G}$ and $\mathrm{T}$ cells of follicles are shown in Fig. 4. In the $\mathrm{G}$ cells, there were no differences in the expression of BMPR-IB between follicle sizes, but 

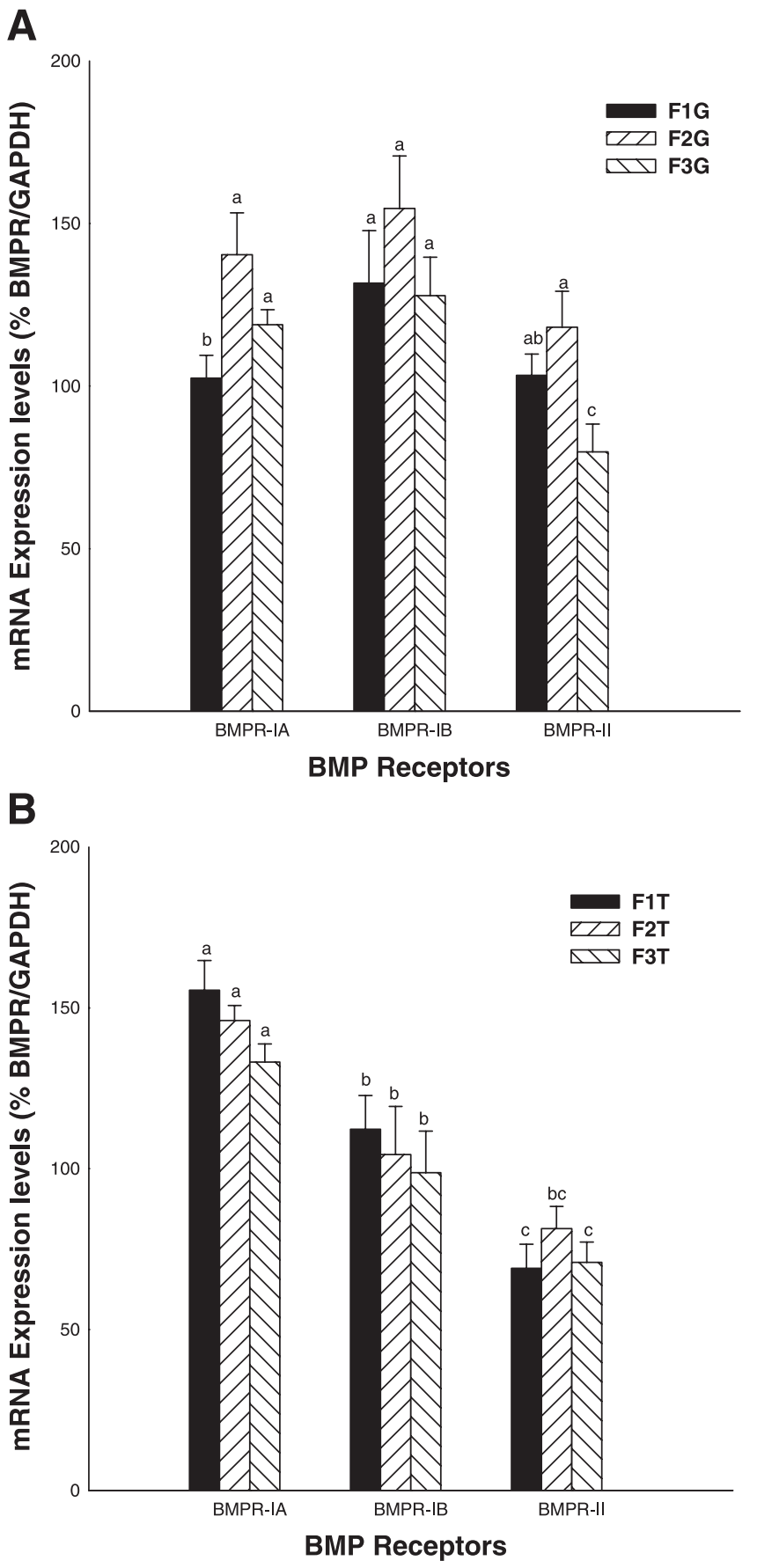

Fig. 4. Levels of expression of mRNA for BMPR-IA, -IB, and -II in the granulosa $(A)$ and theca $(B)$ cells of the largest (F1), second largest (F2), and third largest (F3) follicles of chicken ovary $(n=4)$. Superscripts abcde represent statistical comparison between levels of BMPRs among all receptor types. Bars with different letters are significantly different $(P<0.05)$.

BMPR-IA was lower in the F1 compared with the F2 and F3 follicles. However, BMPR-II expression was higher in the F1G and F2G compared with the F3G.

In the T cells, BMPR-IA, -IB, and -II were expressed at similar levels between follicles. Between tissues, the T tended to express the mRNA for BMPR-IA more than the G. Conversely, the G had higher levels of BMPR-IB and BMPR-II in all follicles than the T except in the F3, where BMPR-II levels were similar.

\section{Effect of BMP-4 and BMP-7 on G Cell Progesterone Production}

The results of our preliminary experiments with freshly isolated cells under short-term incubation of $3 \mathrm{~h}$ showed that, whereas $\mathrm{LH}$ and FSH dose dependently increased progesterone production, IGF-I, BMP-4, and BMP-7 had no effect at all doses tested (0.01-500 ng/ml). TGF- $\alpha$, however, inhibited progesterone production at a maximal dose of $1 \mathrm{ng} / \mathrm{ml}$ (data not shown). However, in culture, both IGF-I and BMPs-4 and -7 dose dependently stimulated progesterone production by G cells cultured in serum-free M199. The effect of the BMPs and IGF-I was evident after $24 \mathrm{~h}$ in culture, was maximal at $48 \mathrm{~h}$, and then decreased at $72 \mathrm{~h}$. The maximum effective concentration was $50 \mathrm{ng} / \mathrm{ml}$ when either BMP-4 or BMP-7 was used. Figure 5 shows the dose effect of the BMPs on $\mathrm{F} 1$ or F3/4 G cells. BMP-4 and -7 at $100 \mathrm{ng} / \mathrm{ml}$ or greater

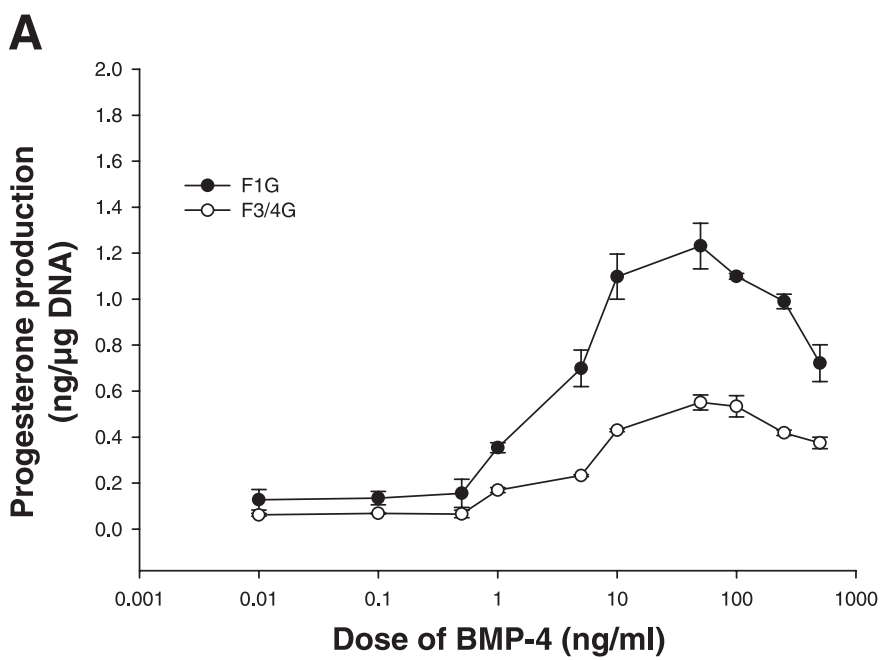

B

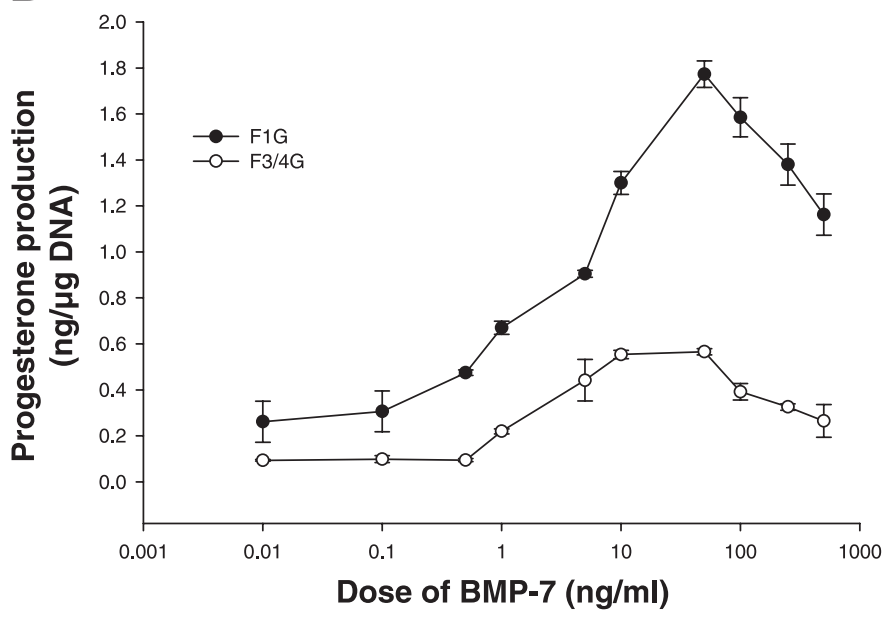

Fig. 5. Effects of different concentrations (0.01-500 ng/ml) of BMP-4 $(A)$ and BMP-7 $(B)$ on progesterone production by granulosa $(\mathrm{G})$ cells cultured from the F1 and F3/4 granulosa follicles of the chicken $(n=16)$. 

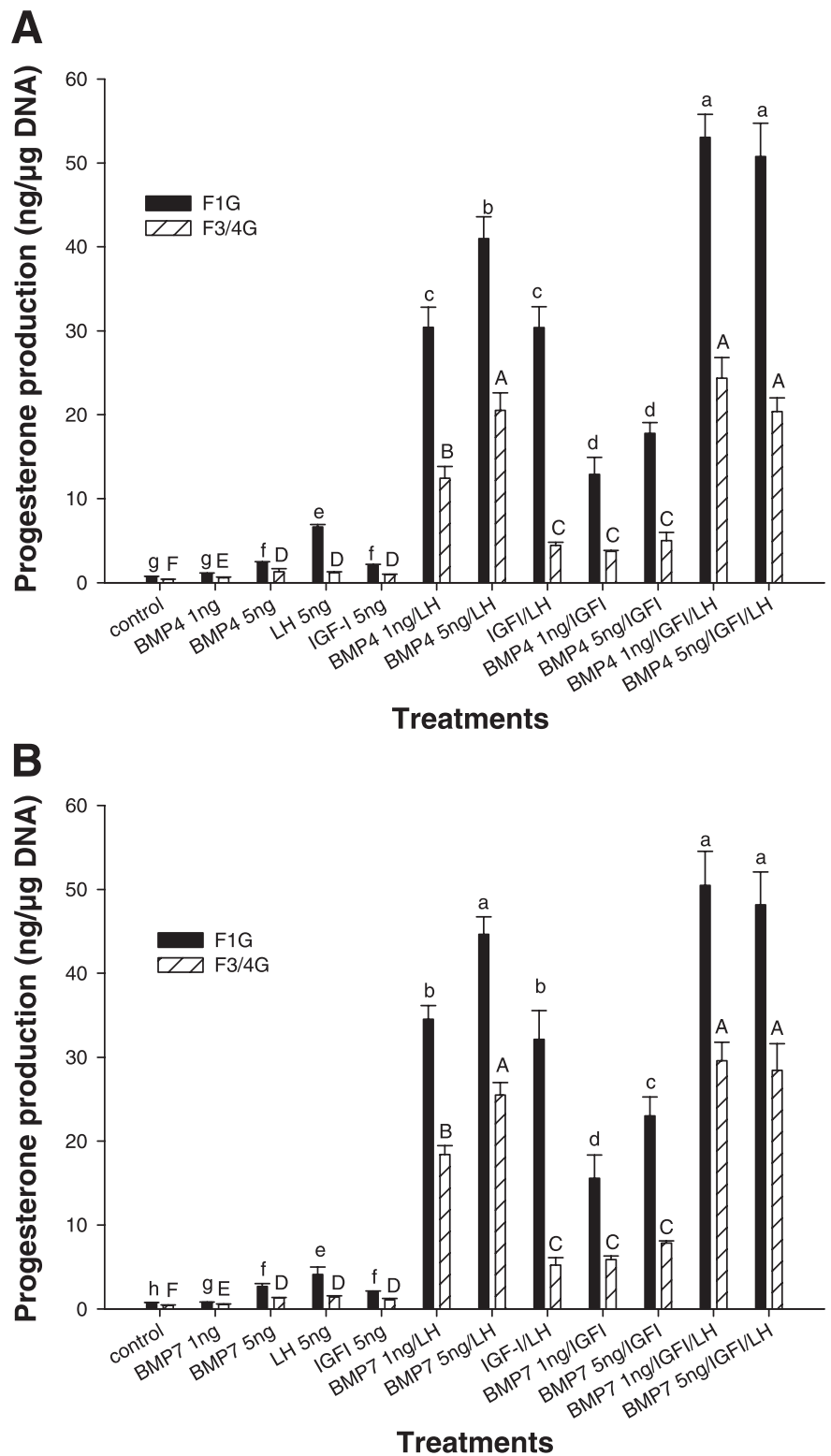

Fig. 6. Effects of BMP-4 and BMP-7 at $1 \mathrm{ng} / \mathrm{ml}$ and $5 \mathrm{ng} / \mathrm{ml}$ alone or in combination with $\mathrm{LH}(5 \mathrm{ng} / \mathrm{ml})$, IGF-I $(5 \mathrm{ng} / \mathrm{ml})$, or LH + IGF-I (5 $\mathrm{ng} / \mathrm{ml}$ each) on progesterone production by granulosa cells of $\mathrm{F} 1 \mathrm{G}$ and F3/4G in vitro $(n=16)$. Superscripts abcdefgh or ABCDEF represent statistical comparison between treatments within the F1 (lower case) or the F3/4 (upper case) follicle cells, respectively. Bars with different letters are significantly different $(P<0.05)$.

decreased progesterone production below that observed for $50 \mathrm{ng} / \mathrm{ml}$. There was a differential responsiveness between the cells of the more mature F1 and the F3/4. At most doses except the maximal dose, the response of cells to either BMP-4 or -7 was similar. At the maximum dose, the $\mathrm{F} 1$ cells were threefold more responsive to BMP-4 than the F3/4 cells, whereas the response to BMP-7 was 4.5-fold.

Figures 6 and 7 show the effects of BMP-4 or -7 on progesterone production at doses of 1 or $5 \mathrm{ng} / \mathrm{ml}$ and of their combination with LH, FSH, or IGF-I. LH, FSH, or IGF-I significantly increased progesterone production individually. The addition of either BMP-4 or BMP-7 along with LH or FSH or IGF-I dose dependently enhanced the effect of the gonadotropins or IGF-I significantly. However, under a combination of LH or FSH with IGF-I, the higher dose of BMPs $(5 \mathrm{ng} / \mathrm{ml})$ had no increased effect beyond that obtained with the lower dose $(1 \mathrm{ng} / \mathrm{ml})$. At all doses and combinations with $\mathrm{LH}$, FSH, or IGF-I, the F1 cells showed significantly higher response than the F3/4 cells. It is noteworthy that BMP- 4 or -7 at a dose similar to IGF-I $(5 \mathrm{ng} / \mathrm{ml})$ was significantly more effective in enhancing LH- or FSHinduced progesterone production than was IGF-I. Com-
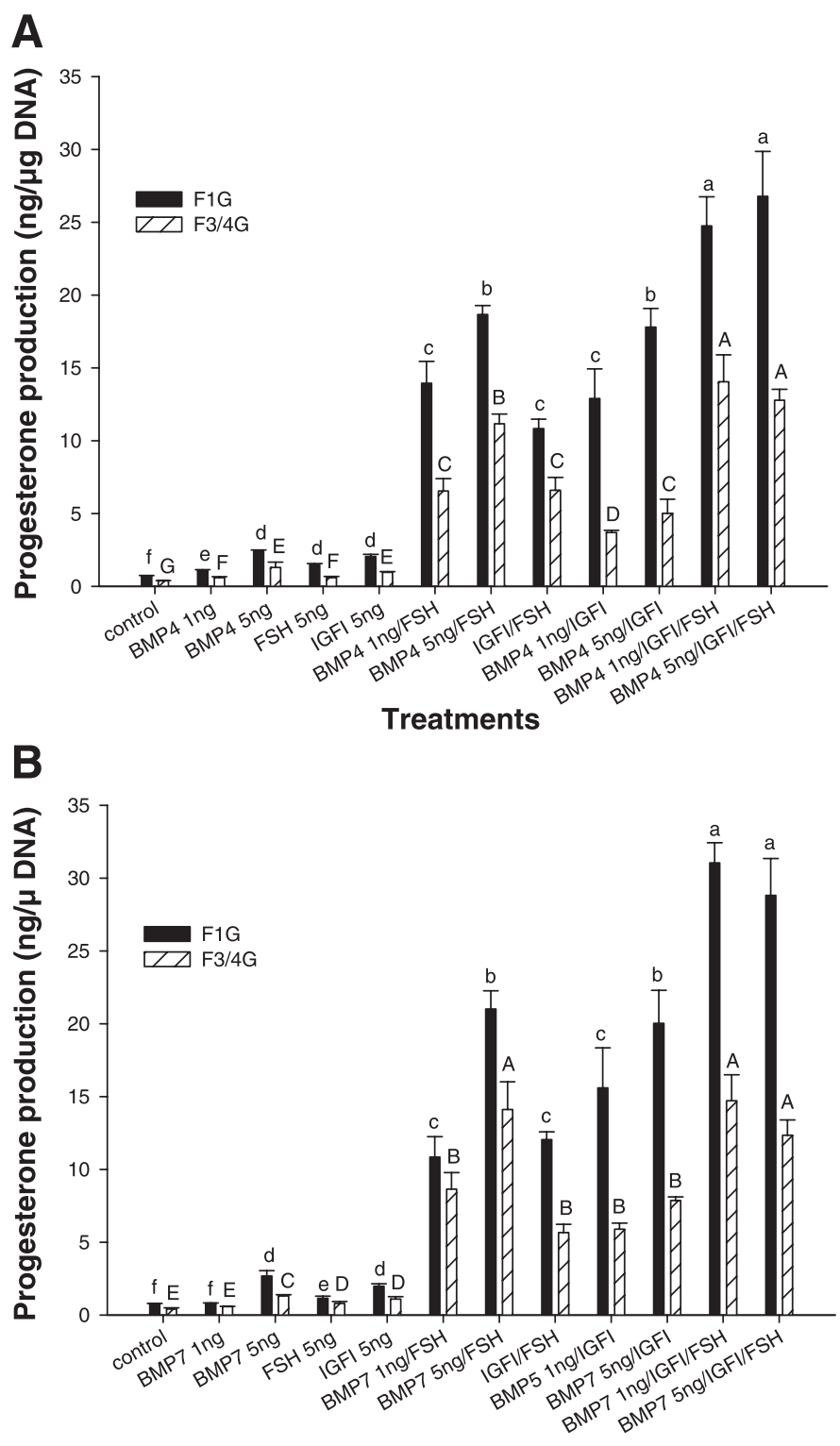

\section{Treatments}

Fig. 7. Effects of BMP-4 and BMP-7 at $1 \mathrm{ng} / \mathrm{ml}$ and $5 \mathrm{ng} / \mathrm{ml}$ alone or in combination with FSH $(5 \mathrm{ng} / \mathrm{ml})$, IGF-I $(5 \mathrm{ng} / \mathrm{ml})$, or FSH + IGF-I (5 $\mathrm{ng} / \mathrm{ml}$ each) on progesterone production by granulosa cells of the F1 and F3/4 in vitro $(n=16)$. Superscripts abcdef or ABCDEFG represent statistical comparison between treatments within the F1 (lower case) or the F3/4 (upper case) follicle cells, respectively. Bars with different letters are significantly different $(P<0.05)$. For enhanced comparisons, some data points depicted here are the same data points as shown in Fig. 6. 


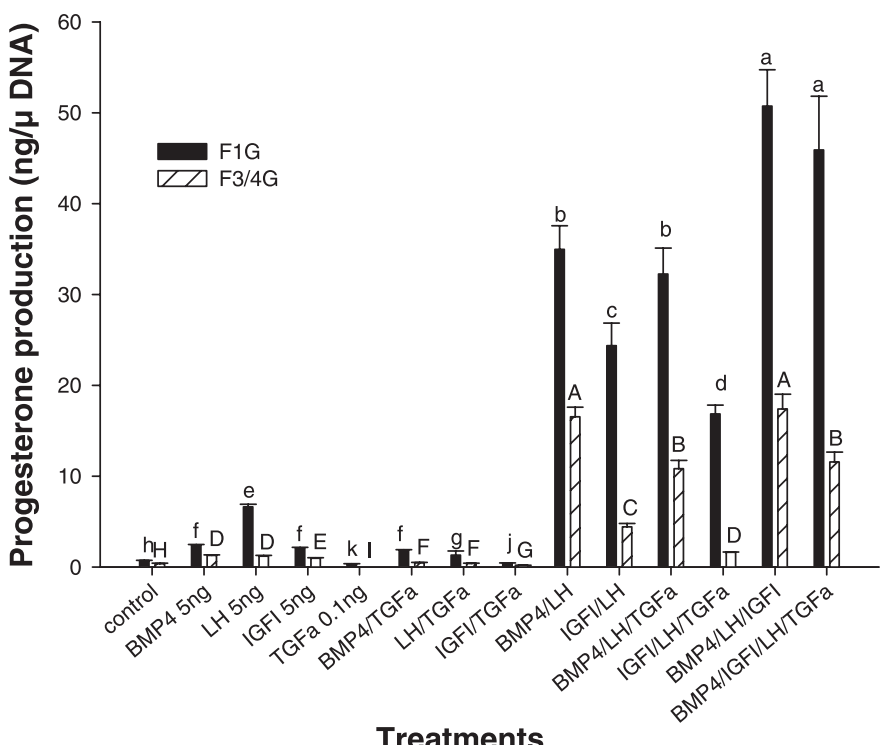

Fig. 8. Effects of BMP-4 and TGF- $\alpha$ individually or in combination with $\mathrm{LH}$ and/or IGF-I on progesterone production by granulosa cells of the F1 and F3/4 follicles $(n=16)$. Superscripts abcdefgh or ABCDEGGH represent statistical comparison between treatments within the F1 (lower case) or the F3 (upper case) follicle cells. Bars with different letters are significantly different $(P<0.05)$. For enhanced comparisons, some data points depicted here are the same data points as shown in Figs. 6 and 7.

paratively, progesterone production in response to the BMPs in combination with FSH was significantly lower than that in combination with $\mathrm{LH}$.

The effect of the BMP-4 in combination with TGF- $\alpha$, LH, or IGF-I is shown in Fig. 8. TGF- $\alpha$ significantly suppressed basal progesterone production by the cells of the F1 and F3/4. It also significantly decreased production in the presence of LH or IGF-I alone. The effect of TGF- $\alpha$ was greater in the F3/4 than in the F1. However, there was little effect of TGF- $\alpha$ on BMP-4induced progesterone production in F1 cells, as the effect was only a marginal decrease in progesterone. However, in the F3/4 cell, TGF- $\alpha$ significantly decreased progesterone in the presence of BMP-4. Although TGF- $\alpha$ significantly decreased LH + IGF-Ienhanced progesterone in both the F1 and F3/4, it had no effect on BMP-4 + LH-enhanced production in the F1 but decreased production from the F3/4. In the presence of BMP-4 + LH + IGF-I, TGF- $\alpha$ again had no effect on progesterone enhancement from the $\mathrm{F} 1$ but lowered the progesterone secretion from the F3/4. Thus the effect of TGF- $\alpha$ in the presence of BMP-4 was dissimilar between the F1 and F3/4 cells, the F1 not being responsive to TGF- $\alpha$ in the presence of BMP-4, whereas the F3/4 was. Similar effects were seen when BMP-7 was substituted for BMP-4 in the culture (data not shown).

\section{Effect of BMPs on G Cell Proliferation in Culture}

Figure 9, $A-D$, shows the DNA content of culture wells after cells have been cultured for $48 \mathrm{~h}$ in the presence of BMP-4 or -7 , with or without LH, FSH, IGF-I, TGF- $\alpha$, or their combinations. Cell proliferation was greater in control wells of the F3/4 cultures than in the F1 cultures as measured by the DNA content of wells. DNA content of the F1 cultures increased by $54 \%$, whereas that in the F3/4 wells increased by $107 \%$ over the 48-h culture period. BMP-7 at concentrations of 1 and $5 \mathrm{ng} / \mathrm{ml}$ stimulated $\mathrm{G}$ cell proliferation. Although BMP-4 marginally increased the DNA content of wells, the increase was not significant. Cell proliferation in the presence of BMP-7 was significantly greater in the culture of F3/4 cells than in the F1 cells. IGF-I alone enhanced cell proliferation in both F1 and F3/4 cells. FSH alone also enhanced cell proliferation in the F3 cells but not in the F1 cells. LH alone had no effect on cell proliferation either in the $\mathrm{F} 1$ or $\mathrm{F} 3 / 4$. However, the addition of either LH or FSH to IGF-I enhanced the proliferative effect of IGF-I significantly, especially in F3/4 follicles. In a similar fashion, BMP-7 significantly enhanced the IGF-I effect. Furthermore, the addition of LH or FSH enhanced the proliferative effect of BMP-7 significantly. The inclusion of BMP-7 along with combination of LH or FSH + IGF-I did increase the effect of the combination of the gonadotropins with IGF-I. It is worthy of note here also that the effect of BMP-7 at a dose similar to IGF-I $(5 \mathrm{ng} / \mathrm{ml})$ in the F3/4 was greater in the different combinations with $\mathrm{LH}$ and FSH.

Figure $9 C$ shows that TGF- $\alpha$ enhanced cell proliferation in both the $\mathrm{F} 1$ and $\mathrm{F} 3 / 4$ cultures but that the effect was significantly greater in the F3/4. BMP-4 had no effect on TGF- $\alpha$ - or IGF-I-enhanced DNA synthesis. Similarly, LH had no effect on TGF- $\alpha$-enhanced cell proliferation, but FSH significantly increased the TGF- $\alpha$ effect in the F3/4 cultures. The combination of IGF-I and TGF- $\alpha$ had a synergistic effect on F3/4 proliferation but not on that of F1. BMP-4 significantly decreased the effect of the combination of TGF- $\alpha$ and IGF-I in both the F1 and F3/4. It also decreased the TGF- $\alpha+$ FSH effect in the F3/4.

Figure $9 D$ shows that TGF- $\alpha$, IGF-I, and BMP-7 independently stimulated DNA synthesis in both F1 and F3/4 cultures. Again, TGF- $\alpha$ in synergy with BMP-7 or IGF-I further increased cell proliferation in the F3/4 wells but not in the F1 cultures. However, the combination of TGF- $\alpha$, IGF-I, and BMP-7 resulted in decreased cell proliferation compared with TGF- $\alpha+$ IGF-I or TGF- $\alpha+$ BMP-7. The addition of LH or FSH in the presence of TGF- $\alpha$ combined with BMP-7 depressed the enhancing effect of TGF- $\alpha$ with BMP-7 on cell proliferation in the $\mathrm{F} 1$.

\section{DISCUSSION}

The results from these studies demonstrate that the genes encoding the mRNA for the BMPs screened for are expressed in the chicken ovary. The expression of the receptors was also detected, suggesting that the BMPs may have a role to play in the regulation of folliculogenesis in the avian ovary. The functional implication of the presence of these BMPs was demonstrated by their support for progesterone production on their own and their enhanced gonadotropin-induced 
Fig. 9. Effects of BMP-4 ( $A$ and $C$ ) and BMP-7 $(B$ and $D$ ) at 1 and $5 \mathrm{ng} / \mathrm{ml}$, alone or in combination with $\mathrm{LH}$ or FSH ( $5 \mathrm{ng} / \mathrm{ml})$, IGF-I ( $5 \mathrm{ng} / \mathrm{ml})$, or LH/ FSH + IGF-I (5 ng/ml each) on DNA synthesis by granulosa cells of the F1 and F3/4 in vitro $(n=16)$. DNA content of wells for F1G and F3/4G controls was $1.08 \pm 0.12 \mu \mathrm{g} / \mathrm{well}$ and $1.74 \pm 0.08 \mu \mathrm{g} /$ well, respectively. Superscripts abcdef or $\mathrm{ABC}$ represent statistical comparison between treatments within the F1 (lower case) or the F3 (upper case) follicle cells. Treatments with superscripts are significantly greater than those of controls. Bars with different letters are significantly different $(P<0.05)$.
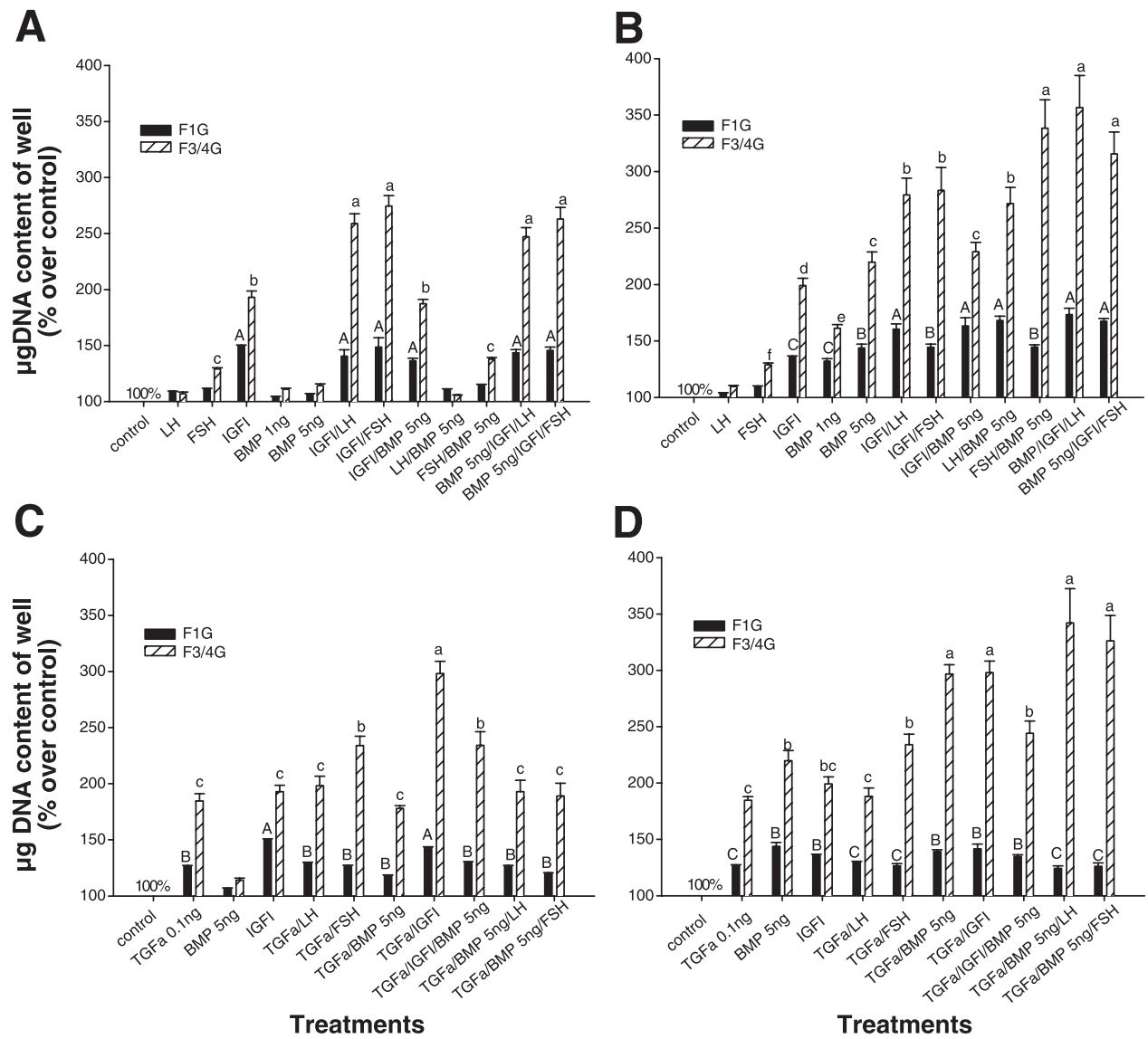

Treatments production. BMP-7 also induced cell proliferation by itself, alone and enhanced by IGF-I and/or gonadotropins, thus indicating a participatory role in follicle growth. This is the first report, to our knowledge, that BMPs are expressed in the avian ovary and involved in the regulation of ovarian function in this species.

BMP-2, $-4,-6$, and -7 were detected in both the $G$ and $\mathrm{T}$ cells of the ovary. BMP expression levels were different between follicles; the two larger, F1 and F2, had higher levels than the F3. There were also differences in expression levels between tissues, suggesting possible paracrine roles. The differential levels of BMP-4 and -7 between follicles may be related to their roles in the follicles, as will be discussed later in this text. The mRNAs for the receptors mediating the actions of these BMPs were present in both $\mathrm{G}$ and $\mathrm{T}$ cells. Although no major differences in expression levels of BMPR-IB were found between follicles, the level of BMPR-IA was lower in the F1G cells. In both tissues, however, the level of BMPR-II was lower in the F3 compared with the F1 and F2. This may mean a reduced role of some BMPs that are ligands for this receptor type. As with the ligands, receptor distribution was different between the $\mathrm{G}$ and the T. This may also mean differential functional levels of the BMPs between the tissues. Although this is a first indication that BMPs are expressed in the avian ovary, there was a recent report that ActRII and ActRIIB, both of which are type II serine/threonine kinase receptors that bind not only activin but also BMPs, are present in chicken follicles (29). The elucidation of the expression of BMP-2, $-4,-6$, -7 and receptor types IA, IB, and II in our study follows in the path of a similar study in the rat, in which BMP-4, - $6,-7$, and all of the receptors have been identified $(28,34)$. In the sheep ovary, the immunolocalization of the receptors has also been reported (30). However, a major difference exists in compartmentalization of the BMPs. Whereas the BMP-4 and -7 are confined to the $\mathrm{T}$ alone and BMP- 6 to the oocyte in mammals, the BMPs were expressed in both $\mathrm{G}$ and $\mathrm{T}$ in the chicken. Our data show that BMPR-IB and -II expression was higher in the $G$ than in the $T$, suggesting that the $\mathrm{G}$ may be a major target for BMP actions. Furthermore, the IB types are expressed uniformly in G of all follicle sizes. These findings are consistent with the distribution of mRNA and immunostaining in both rat and sheep ovaries. In contrast, BMP-II mRNA levels were different between follicles in the chicken G. It showed increasing levels with follicle development. BMPR-II has been shown to perform an important role in mediating the actions of BMPs. BMP-4, -7, and -15 [growth differentiation factor 9 (GDF-9)] bind first to the type II receptor and subsequently phosphorylate the type I receptors to trigger the Smad protein-signaling pathways $(12,13,34)$. It is not clear, however, which type I receptor is specific for which ligand. Blocking the synthesis of BMPR-II completely prevented G cell thymidine incorporation by BMP-15 (GDF-9) (34). 
Thus the lower expression level of BMPs in the F3G, coupled with the lower BMPR-II, may lower the biological activity in the F3 compared with F2 and F1. This may be a mechanism for maintaining differential development in the follicular hierarchy of the chicken ovary.

The lack of effect of BMP-4 and -7 and IGF-I on progesterone production under short-term incubation compared with the effect of the LH and FSH suggests a role as differentiation factors rather than involvement in acute processes. It also suggests that these differentiation factors act through different intracellular signaling pathways that are different from those that mediate the actions of LH, FSH, and TGF- $\alpha$. Both BMP-4 and BMP-7 increased progesterone production by cultured G cells. Effects were dose dependent. They also enhanced LH, FSH, IGF-I, and LH or FSH + IGF-I effects on progesterone production. The synergistic effect of the BMPs with LH or FSH is striking. It is more surprising that the BMPs showed greater synergism with the gonadotropins than did IGF-I at a similar dose of $5 \mathrm{ng} / \mathrm{ml}$. At this dose, both chicken IGF-I and each of the BMPs alone had comparable effects on progesterone production. Moreover, the $\mathrm{ED}_{50}$ values of both were similar $(2 \mathrm{ng} / \mathrm{ml})$. Whether this means that the chicken follicles have preferential requirement for BMP-4 and - 7 over IGF-I for differentiation needs to be determined. The lack of significant difference between the effects of BMP-4 and BMP-7 on progesterone production at the doses tested with LH, FSH, or IGF-I suggests that both may equally function in follicular differentiation. Significantly, the response of the less mature F3 cells was lower than that of the F1 cells in all treatments. This differential response may be connected with the lower level of BMPR-II expression discussed earlier. Thus, in vivo, the lower expression/ secretion of BMP-4 or -7 detected in the presence of lower BMPR-II will also result in lower progesterone production and therefore keep the F3 less differentiated. In the context that progesterone is considered to be the major ovarian feedback hormone for LH release and ovulation in the chicken and, as such, a functional equivalent of estradiol in humans, the effects of BMP-4 and BMP-7 on progesterone in this study agree with the results of a similar study in the rat (28), which showed that BMP-4 and -7 stimulated the secretion of estradiol by rat granulosa cells. Recently, Souza et al. (30) also reported that BMP-2 enhanced estradiol production from sheep granulosa cells. In contrast, however, BMP-4 and -7 inhibited progesterone production in both rat and sheep $(15,28)$. There is currently no report on the role of BMPs in the T cells. However, a recent study using human theca-like tumor cell (HOTT) cultures showed that BMP-4 inhibited basal, or forskolin- and cAMP-stimulated androstenedione but increased progesterone production (3). Although we did not determine the effects of BMP- 4 or -7 in the $\mathrm{T}$ in the current study, the detection of the mRNA for the peptides and receptors suggests that they might have a role in $\mathrm{T}$ cell androgen or estrogen production and cell proliferation. This remains to be tested.
EGF and TGF- $\alpha$ are paracrine growth factors that regulate follicular development in the ovary of the chicken $(39,40)$. The antagonistic effect of EGF and TGF- $\alpha$ on basal or gonadotropin-stimulated progesterone production by chicken $\mathrm{G}$ cells is well known $(18,23$, $35,36)$. Its effects decreased with follicular development, thus allowing follicles to increase basal and gonadotropin-stimulated progesterone production and differentiation. In the present study, TGF- $\alpha$ inhibited basal, LH, and IGF-I-stimulated progesterone secretion, but its effect on progesterone production was different between F1 and F3 cells in the presence of BMP-4 or -7. The effect of TGF- $\alpha$ on progesterone production was voided in the $\mathrm{F} 1$ in the presence of BMPs with or without LH + IGF-I, but it was still effective in the F3/4 in the presence of the BMPs, with or without LH + IGF-I. This interaction between BMP and TGF- $\alpha$, we suspect, may be the underlying mechanism for the differential effects of TGF- $\alpha$ as the follicle matures through the hierarchy to become the F1. Thus the normal (in vivo) lower responsiveness of the F3 cells to LH, FSH, IGF-I, or their combinations may be related to the intraovarian interaction between BMPs and EGF and/or TGF- $\alpha$ that modulates the responsiveness of $G$ cells to endocrine factors with follicular maturation. Indeed, our data showed that BMP-4 and BMP-7 also increase with follicular development, an increase that may serve to counteract the effect of TGF- $\alpha$. The mechanism by which BMP suppresses TGF- $\alpha$ effect is not yet known but may involve the suppression of TGF- $\alpha / \mathrm{EGF}$ receptor expression, since this receptor level also decreases with follicular growth (16).

BMP-7, but not BMP-4, exerted a stimulatory effect on $\mathrm{G}$ cell proliferation, which indicates its involvement in follicular growth. However, its effect alone was higher than that of IGF-I at a similar concentration and had a similar effect in synergism with LH or FSH in the F1. In the F3/4, the synergism with FSH was higher compared with IGF-I + LH or BMP + LH. This may be due to the greater concentration of FSH receptors in this follicle size than in the $\mathrm{F} 1$. TGF- $\alpha$, like IGF-I and BMP-7, enhanced cell proliferation in both F1 and F3/4 cultures. It also had synergistic effects with IGF-I or BMP-7 in the F3/4. Although TGF- $\alpha$, BMP-7, and IGF-I individually enhanced F1 cell proliferation in culture, there was no synergism between TGF- $\alpha$ and BMP-7 or IGF-I. Although BMP-4 did not affect cell proliferation on its own, it seemed to show an inhibitory effect in the presence of TGF- $\alpha$ and IGF-I in both F1 and F3/4 cultures. In contrast to the LH effect with BMP-7 or IGF-I, LH did not enhance the TGF- $\alpha$ effect in either F1 or F3/4 and, in fact, $\mathrm{LH}$ and FSH depressed the enhancing effect of BMP-7 + TGF- $\alpha$ in $\mathrm{F} 1$ culture. These results suggest that there is an array of complex mechanisms that controls the enhancement of cell proliferation during the growth period and the reduction/inhibition of growth toward maturation. Thus BMP-4 and -7, and indeed LH and FSH, may be candidates for regulating TGF- $\alpha$ and IGF-I effects on growth of follicles during development. BMPs are 
known to induce bone cell proliferation and differentiation $(27,38)$. In mammalian studies, only BMP-6, -7, and -15 had been shown to stimulate ovarian cell proliferation (20-22, 34). Otsuka and Shimasaki (20) showed that BMP-7 and -15 promoted rat granulosa cell mitotic activity and that this effect was enhanced in the presence of an oocyte. The significantly higher response by the F3/4 cells in this chicken study is consistent with previous reports that the less mature chicken cells have greater proliferative capability than cells from more mature follicles $(18,23,35)$. In the current study, the F3/4 cultures had significantly greater DNA content than the F1 cultures, either with or without stimulation. This indicates greater proliferation of cells in the F3/4 and that BMP-7, IGF-I, TGF- $\alpha$, and their combination enhanced this capacity. It would seem, therefore, that the major role of BMP-7 in the F3 is to enhance growth while maintaining a lower-level role in differentiation. On the other hand, its major roles in the F1 and F2 may be more of differentiation than of growth, together with BMP-4 and both binding to the same receptors. BMP-4 also seems to be involved in inhibiting too rapid growth during the growth phase and probably in inhibiting growth to allow for differentiation processes during the final stages of maturation.

In conclusion, we have shown that BMP-2, $-4,-6$, and -7 , and the receptors that mediate their actions, are present in the chicken follicles. In the granulosa, BMP-4 and - 7 were shown to enhance basal and gonadotropin-stimulated progesterone production and antagonize TGF- $\alpha$ actions and therefore may be involved in follicular differentiation and maintenance of the follicular hierarchy. BMP-4 and -7 also showed a role in the regulation of granulosa cell proliferation and could therefore be involved in follicular growth.

We thank Hubbard Europe for providing the broiler breeder chicks.

\section{DISCLOSURES}

This work was supported by the "5th Framework Programme Grant” from the European Union (QLRT-2000-1732).

\section{REFERENCES}

1. Arkell R and Beddington RSP. BMP-7 influences pattern and growth of the developing hindbrain of mouse embryos. Development 124: 1-12, 1997.

2. Ashique AM, Fu K, and Richman JM. Signalling via type IA and type IB bone morphogenetic protein receptors (BMPR) regulates intramembranous bone formation, chondrogenesis and feather formation in the chicken embryo. Int $J$ Dev Biol 46: 243-253, 2002.

3. Dooley CA, Attia GR, Rainey WE, Moore DR, and Carr BR. Bone morphogenetic protein inhibits ovarian androgen production. J Clin Endocr Metab 85: 3331-3337, 2000.

4. Dube JL, Wang P, Elvin J, Lyons KM, Celeste AJ, and Matzuk MM. The bone morphogenetic protein 15 gene is $\mathrm{X}$ linked and expressed in oocytes. Mol Endocrinol 12: 1809-1817, 1998.

5. Galloway SM, McNatty KP, Cambridge LM, Laitnen MPE, Juengel JL, Jokiranta TS, McLaren RJ, Luiro K, Dodds KG, Montgomery GW, Beattie AE, Davis GH, and Ritvos O. Mutations in an oocyte-derived growth factor gene (BMP-15) cause increased ovulation rate and infertility in a dose-sensitive manner. Nat Genet 25: 279-283, 2000.

6. Gilbert AB, Evans AJ, Perry MM, and Davidson MH. A method for separating the granulosa cells, the basal lamina and the theca of the preovulatory ovarian follicle of the domestic fowl (Gallus domesticus). J Reprod Fert 50: 179-181, 1977.

7. Helder MN, Karg A, Bervoets TJM, Vukicevic S, Burger EH, D'Souza RN, Woltegens JHM, Karsentry G, and Bronkers ALJJ. Bone morphogenetic protein 7 (Osteogenin protein-1, OP-1) and tooth development. J Dent Res 77: 545-554, 1998.

8. Jena N, Martin-Seisdedos C, McCue P, and Croce CM. BMP-7 null mutation in mice: developmental defects in skeleton, kidney and eye. Exp Cell Res 230: 28-37, 1997.

9. Labarca $\mathbf{C}$ and Paigen K. A simple, rapid and sensitive DNA assay procedure. Anal Biochem 102: 344-352, 1980.

10. Lee WS, Otsuka F, Moore RK, and Shimasaki S. Effects of bone morphogenetic protein-7 on folliculogenesis and ovulation in the rat. Biol Reprod 65: 994-999, 2001.

11. Lyons KM, Petton RW, and Hogan BLM. Patterns of expression of murine Vgr-1 and BMP-2a RNA suggest that transforming growth factor-beta-like genes coordinately regulate aspects of embryonic development. Genes Dev 3: 1657-1668, 1989.

12. Macias-Silva M, Hoodless PA, Tang SJ, Buchwald M, and Wrana JL. Specific activation of Smad1 signalling pathways by the BMP-7 type-I receptor ALK2. J Biol Chem 273: 25628$25636,1998$.

13. Miyazono K, Kusanagi $\mathbf{K}$, and Inoue $\mathbf{H}$. Divergence and convergence of TGF-beta/BMP signalling. J Cell Physiol 187: 265-276, 2001.

14. Monroe DG, Jin DF, and Sanders MM. Estrogen opposes the apoptotic effects of bone morphogenetic protein-7 on tissue remodelling. Mol Cell Biol 20: 4626-4634, 2000.

15. Mulsant P, Lecerf F, Fabre S, Schibler L, Monget $P$, Lanneluc I, Pisselet C, Riquet D, Monniaux D, Callebaut I, Cribiu E, Thimonier J, Teyssier J, Bodin L, Conie Y, Chitour N, and Elsen JM. Mutation in bone morphogenetic protein receptor-IB is associated with increased ovulation rate in Booroola Merino ewes. Proc Natl Acad Sci USA 98: 5104-5109, 2001.

16. Onagbesan OM, Gullick W, Woolveridge I, and Peddie MJ. Immunohistochemical localization of EGF receptors and EGF/ TGFalpha-like peptides in chicken ovarian follicles. $J$ Reprod Fertil 102: 147-153, 1994.

17. Onagbesan OM, Mast J, Godeerris B, Decuypere E. Effects of TNF-alpha on LH and IGF-I modulated chicken granulosa cell proliferation and progesterone production during follicular maturation. J Reprod Fertil 120: 433-442, 2000.

18. Onagbesan OM and Peddie MJ. Effects of insulin-like growth factor-I and interactions with transforming growth factor-alpha and LH on chicken granulosa cell proliferation and progesterone production in culture. J Reprod Fertil 104: 259-265, 1995.

19. Onagbesan OM, Vleugels B, Buys N, Bruggeman V, Safi M, and Decuypere E. Insulin-like growth factors in the regulation of avian ovarian functions. Dom Anim Endocrinol 17: 299-313, 1999.

20. Otsuka F and Shimasaki S. A negative feedback system between oocyte bone morphogenetic protein 15 and granulosa cell kit ligand: its role in regulating granulosa cell mitosis. Proc Natl Acad Sci USA 99: 8060-8065, 2002.

21. Otsuka F, Yamamoto S, Erickson GF, and Shimasaki S. Bone morphogenetic protein-15 inhibits follicle stimulating hormone (FSH) action by suppressing FSH receptor expression. J Biol Chem 276: 11387-11392, 2001.

22. Otsuka F, Yao Z, Lee T, Yamamoto S, Erickson GF, and Shimasaki S. Bone morphogenetic protein-15. Identification of target cells and biological functions. J Biol Chem 275: 3952339528,2000

23. Peddie MJ and Onagbesan OM. Chicken granulosa cell proliferation and progesterone production in culture: effects of epidermal growth factor and theca secretions. Gen Comp Endocrinol 94: 341-356, 1994. 
24. Roberts RD and Ellis RC. Mitogenic effects of fibroblast growth factors on chicken granulosa and theca cells in vitro. Biol Reprod 61: 1387-1392, 1999.

25. Rosen V, Thies RS, and Lyons K. Signalling pathways in skeletal formation: a role for BMP receptors. Ann NY Acad Sci USA 785: 59-69, 1996.

26. Safi M, Buys N, Onagbesan OM, Vleugels B, and Decuypere E. Quantification of inhibin/activin a and bA subunit messenger ribonucleic acid by competitive reverse transcriptionpolymerase chain reaction in chicken granulosa cells during follicular development. Biol Reprod 59: 1047-1054, 1998.

27. Sampath TK, Maliakal JC, Hauschka PV, Jones WK, Sasak H, Turker RF, White KH, Coughlin JE, Tucker MM, Pang RHL, Corbett C, Ozkaynak E, Oppermann H, and Rueger DC. Recombinant human protein-1 (hOP-1) induces new bone formation in vivo and stimulates osteoblast proliferation and differentiation in vitro. J Biol Chem 267: 20352-20362, 1992.

28. Shimasaki S, Zachow RJ, Li D, Kim H, Iemura S, Ueno N, Sampath K, Chang RJ, and Erickson GF. A functional bone morphogenetic protein system in the ovary. Proc Natl Acad Sci USA 96: 7282-7287, 1999.

29. Slappy SN and Davis AJ. Expression pattern of messenger ribonucleic acid for the activin type-II receptors and the inhibin/ activin subunits during follicular development in broiler breeder hens. Poult Sci 82: 338-344, 2003.

30. Souza CJH, Campbell BK, McNeilly AS, and Baird DT. Effect of bone morphogenetic protein 2 (BMP2) on oestradiol and inhibin A production by sheep granulosa cells, and localization of BMP receptors in the ovary by immunohistochemistry. Reproduction 123: 363-369, 2002.

31. Souza CJH, MacDouglas C, Campbell BK, McNeilly AS, and Baird DT. The Booroola (FecB) phenotype is associated with a mutation in the bone morphogenetic receptor type IB (BMPRIB) gene. J Endocrinol 169: R1-R6, 2001.

32. Suzuki A, Thies RS, Yamaji N, Song JJ, Wozney JM, Murakami $\mathbf{K}$, and Ueno $\mathbf{N}$. A truncated bone morphogenetic protein receptor affects dorso-ventral patterning in the early
Xenopus embryo. Proc Natl Acad Sci USA 91: 10255-10259, 1994.

33. Van As P, Janssens W, Onagbesan OM, Bruggeman V, Buys N, Sanders J, Vandergeyten S, Darras VM, and Decuypere E. Quantification of growth hormone receptor extra(GHRe) and intra-cellular dolain (GHRi) gene expression in chicken liver by quantitative competitive RT-PCR. Gen Comp Endocrinol 122: 213-224, 2001.

34. Vitt UA, Mazerbourg S, Klein C, and Hsueh AJW. Bone morphogenetic protein receptor type II is a receptor for growth differentiation factor-9. Biol Reprod 67: 473-480, 2002.

35. Vleurick L, Vanmontfort D, Bruggeman V, Huybrechts L, and Decuypere E. The influence of epidermal growth factor on progestreone production in isolated chicken granulosa cells. Exp Clin Endocrinol (Life Sci Adv) 14: 39-45, 1995.

36. Volentine KK, Yao HHC, and Bahr JM. Epidermal growth factor in the germinal disc and its potential role in follicular development in the chicken. Biol Reprod 59: 522-526, 1998.

37. Wilson T, Wu XY, Juengel JL, Ross IK, Lumsden JM, Lord EA, Dodds KG, Walling GA, McEwan JC, O'Connell AR, McNatty KP, and Montgomery GW. Highly prolific Booroola sheep have a mutation in the intracellular kinase domain of the bone morphogenetic protein IB receptor (ALK-6) that is expressed in both the oocytes and granulosa cells. Biol Reprod 64: 1225-1235, 2001.

38. Wozney JM and Rosen V. Bone morphogenetic protein and bone morphongenetic protein gene family in bone formation and repair. Clin Orthop 346: 26-37, 1998.

39. Yao HHC and Bahr JM. Chicken granulosa cells show differential expression of epidermal growth factor (EGF) and luteinizing hormone (LH) receptor messenger RNA and differential responsiveness to EGF and $\mathrm{LH}$ dependent upon location of granulosa cells to the germinal disc. Biol Reprod 64: 1790-1796, 2001.

40. Yao HHC and Bahr JM. Germinal disc-derived epidermal growth factor: a paracrine factor to stimulate proliferation of granulosa cells. Biol Reprod 64: 390-395, 2001. 